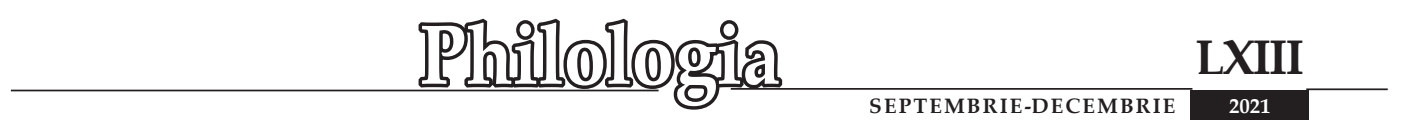

https://doi.org/10.52505/1857-4300.2021.3(315).12

CZU:81’373:398.91=00

\section{THE SEMANTIC ANALYSIS OF MONEY-RELATED PROVERBS IN THREE LINGUACULTURES}

\section{Inna COLENCIUC}

Doctorand, Școala doctorală științe umanistice, politice și ale comunicării

E-mail: icolenciuc@yahoo.com

ORCID: https://orcid.org/0000-0001-6404-7498

Universitatea Liberă Internaţională din Moldova

\section{Analiza semantică a proverbelor legate de conceptul „bani” în trei lingvoculturi}

\begin{abstract}
Proverbs, being an element of ethnoculture, reflect the mentality, basic values of people, and their idea of the surrounding world. The author of the article accounts for the necessity to study money-related proverbs and notes that money is an unalienable part of the contemporary society, and consequently, it represents the material for psychological, sociocultural and linguistic research. Our aim is to conduct a comparative semantic analysis of proverbs in English, Romanian and Russian. The material for the research was 150 proverbs in the corresponding linguacultures. The author classifies proverbs by the semantic basis, identifies similarities and differences of English, Romanian and Russian proverbs.
\end{abstract}

Keywords: paremiology, proverb, money, semantic analysis, lexical unit, linguaculture, linguaculturology.

\section{Rezumat}

Proverbele, fiind un element al etnoculturii, reflectă mentalitatea, valorile de bază ale oamenilor și ideea lor despre lumea înconjurătoare. În acest articol se explică necesitatea studierii proverbelor legate de conceptul „bani” și se constată că banii sunt o parte inalienabilă a societății contemporane, în consecință reprezentând materialul pentru o cercetare de natură psihologică, socioculturală și lingvistică. În articol se face o analiză semantică comparativă a proverbelor în limbile engleză, română și rusă. Materialul pentru cercetarea dată a constat din 150 de proverbe în lingvoculturile corespunzătoare. Proverbele sunt clasificate pe baza analizei semantice, identificându-se asemănările și diferențele dintre proverbele engleze, române și ruse.

Cuvinte-cheie: paremiologie, proverb, bani, analiză semantică, unitate lexicală, lingvocultură, lingvoculturologie.

Changes taking place in our society nowadays are accompanied by the growth of different problems in public life. Among them we can highlight, first of all, the problem of interest in money directly related to a person's life in the 


\section{LXIII

society, which determines his/her behavior, preferences, the level of development of needs, reflecting the individual and national characteristic of personality, customs and traditions, social status and the spiritual world. The concept "money" has an economic value, but its meaning is closely intertwined with psychological, social, cultural and linguistic ones. In addition to economic feasibility, people's opinion about money is regulated by value systems and norms of behavior, social attitudes, stereotypes and prejudices, myths, superstitions, etc. Viewed from an attitudinal perspective, money has always triggered different feelings in people, it has been admired or cursed; it has been craved for and disdained. Chronicles, old and contemporary judicial documents, books on psychology and literary works are "the source of assessment on the presence or absence of material or moral well-being measured with the help of money" (Colenciuc, 2016, p. 178).

Linguaculturology as a new interdisciplinary sphere of humanitarian research appeared at the end of the $20^{\text {th }}$ century. A unified approach to the study of language and culture is a topical field of modern linguistics. "Linguistic and cultural studies are the source of new knowledge about the peculiarities of the culture of particular people, their mentality, traditions and way of life" (Permjakov, 1988, p. 35). This idea finds reflection in the work on linguistic culturology written by Moldovan scholar Elena Dragan. Linguaculturology originated in Russia and is now a rapidly expanding field of research, attracting a great number of scholars. Knowledge, wisdom and experience found their vivid reflection in the paremiological collection of the language. Paremiology, the study of proverbs, is one of the integral parts of linguaculturology as it examines the living communicative processes and the relationship of the language expressions and the mentality of the people.

For this contribution, we have also consulted the works of the following scholars in the field of paremiology: Mielder W., Norrick N., Whiting B., Hjelmslev L, Osheva E. and others. In these studies, proverbs are explored in both linguistic and cultural paradigms. They are traditional, pithy, often formulaic or figurative, fairly stable and generally recognizable.

From a semiotic point of view, Lous Hjelmslev defines a proverb as a "sign integrating an expression and a content plane" (1987, p. 123). The view of proverbs as signs of a specific ethnic group is central to linguaculturology.

From a linguacultural perspective, the proverb is regarded as an autosemantic one-sentence precedent text (i.e representative, traditional, culturally significant text embodying a certain cultureme and message) (Nordahl, 2011, p. 17).

Elena Osheva considers the proverbs to be the source of instruction and teaching which are transmitted in a laconic form to other generations. The correct and appropriate use of proverbs gives the speech a unique originality and special expressiveness (2013, p. 227).

Bartlette Whiting gives the following definition to the paremiological units: „A proverb is an expression which, owing its birth to the people, testifies to its origin in form and phrase. (...) Some proverbs have both a literal and figurative meaning, either of which makes perfect sense; but more often they have but one of the two." (2007, p. 25). 
Notable German proverb scholar Wolfgang Mieder defines paremiological units as short, generally known sentences of the folk that contains wisdom, truths, morals, and traditional views in a metaphorical, fixed and memorizable form and that are handed down orally from generation to generation (2004, p. 7).

The author of this article regards proverbs as linguistic units that have educatory, cultural, aesthetic, artistic and figurative characteristics. Proverbs are in touch with truth and human wisdom, with the traditions and customs of the people. Most of these laconic traditional texts are centuries old and can be traced back to the beginning of human civilization. Nowadays they keep making a bridge across generations belonging to the people of same culture and to the whole world.

We account for the necessity to study money-related proverbs in different languages as they reflect the rich historical experience of peoples, representations related to work, life and culture. The material for the research was 150 proverbs in the English, Russian and Romanian languages. The comparison of "money" proverbs in the three languages shows how many things they have in common and, in turn, contributes to their better understanding and use. We have resorted to the following methods of research: comparative - to find similarities and differences in three linguacultures; axiological - to consider culture as a system of material values, a systemic method - to show the relationship between language and culture; and the method of continuous sampling - to obtain the research material.

In the study, we analyzed the proverbs in the corresponding languages selected according to the following criteria:

\section{Lexical units nominating the concept of "money"}

All 50 proverbs in the English language contain the lexeme "money". Most of the paremiological units in the Russian language have the lexeme «деньги» (30), but there also are lexical units such as «золото/ золотой» (4), «богатство/ богатый» (12), «рубль» (2), «копейка» (1), «грош» (2), «серебро» (1), «алтын» (1), and «бумажки» (1). In the Romanian language, there are the following lexemes: „ban/ bani” (44), „bogat” (1), ,aur” (3), ,argint” (1), and „economie” (1). Thus, we can come to the conclusion that the lexeme „money”/ «деньги»/ „ban/ bani” is the core of the concept; a number of proverbs in the Romanian and Russian languages contain lexical units denoting material from which money is made, the name of currency units and the state of possession of money.

\section{The stylistic devices characterizing the paremiological unit}

Among the stylistic devices metaphor prevails in all three languages. For instance, in the English language, we have encountered the following metaphors in "money" proverbs: Money is a bottomless sea in which honor, conscience and truth may be drowned, Money is the root of all evil, Ready money is ready medicine and Money will be slave or master. In the Russian language there are many examples of metaphors in paremiological units: Деньги не голова: наживное дело; Деньги - забота, мешок-тягота; Деньги не щепки, счетом крепки Деньги пух - только дунь на них - и нет; Богатство - вода: пришла и ушла. In the Romanian language, we can also find metaphors in money-related 
proverbs: Banul e ochiul dracului; Banul e ciocoi de uși multe; Banul e o mică roată, ce-nvârtește lumea toată.

Another stylistic device characterizing money-related proverbs in the analyzed languages is personification: in English - Money greases the machine in the long run; Money opens all doors, Money talks; in Russian - Не нас деньги наживали, а мы деньги нажили; Бог любит веру, а деньги счет; Деньга деньгу наживает; Деньга и камень долбит; Когда деньги говорят, тогда правда молчит; in Romanian - Banul deschide ușile fără chei; Banii n-au ochi să vadă pe ce îi cheltuiești; Banul te învață a grăi și hainele a merge.

Comparison can also be found in all three languages: in English - Money, like promises is easier made than kept; Nothing but money is sweeter than honey; in Russian - Богатство спеси сродни; Деньги, что каменья: тяжело на душу ложатся; in Romanian - Banii nu se culeg de la trunchi, ca surcelele; Banii şi tinerețea sunt ca apa în timpul revărsării; Banul e ca puşca vânătorului: când vede vânat, trage.

Parallelism is used in the following proverbs: in English - Money borrowed is money spent; in Russian - С деньгами мил, без денег постыл; Были бы бумажки, будут и милашки; Слову - вера, хлебу -мера, деньгам - счет; in Romanian Banul ascuns în pământ, nici creşte, nici rodeşte; Ai bani, ai prieteni; $n$-ai bani, n-ai prieteni.

A distinctive feature of paremiological units in the corresponding linguacultures is a rather frequent use of rhyme: in English - Nothing but money is sweeter than honey; People are funny about their money; in Russian - Пусти душy в ад, будешь богат; Захочешь добра - посыпь серебра; Золото не говорит, да много творит; in Romanian - Ban găsit - ban vrăjit; Banul te duce, banul te-aduce; Dacă ai bani, ai prieteni și dușmani; Banul e o mică roată, ce-nvîrtește lumea toată.

In the Russian language, we can come across a kind of metonymy, synecdoche: Добр Мартын, коли есть алтын; Есть грош, так будет и рожь; Богатыйто с рублем, а бедный-то со лбом; Хлеб да живот - и без денег живет (Denisenkova, 2015, p. 38).

Antonomasia is presented in the following proverb: Добр Мартын, коли есть алтын.

The following Russian proverbs represent the antithesis: Богатство гинет, а нищета живет; Богатый-то с рублем, а бедный-то со лбом.

\section{The semantic analysis}

Conducting the research, we have identified the following common semantic groups of paremiological units:

Money is the driving force of society. The group is represented by such proverbs as: in English - Money is power; Money answers all things; Money makes the world go round; Money makes the ball roll; Money makes the pot boil; Money greases the axle; Money greases the machine in the long run; in Russian - Золото и на воде плавает; Денег нет, так подушка под головой не вертится; И слова 
не скажи, только грош покажи; in Romanian - Banul te duce, banul te-aduce; Banul are trecere în orice curte; Banul face lumină în loc întunecos.

The secondary role of money in human life. The following proverbs make part of this group: in English - Money isn't everything in life; Money isn't worth a thing except to use in buying something; Money doesn't make the character; in Russian - Деньги не голова: наживное дело; Не деньги нас наживали, а мы деньги нажили; Хлеб да живот - и без денег живет; in Romanian - Poţi cumpăra sânge cu bani, dar nu şi viaţa; Și cu bani fericit tot nu ești.

The harmful effect of money on people. In this semantic group of paremiological units, two subgroups can be distinguished: the negative effect of money on a person's character and value system. and the evil nature of money. The following proverbs belong to the first group: in English-Money is a bottomless sea in which honor, conscience and truth may be drowned; Money is the root of all evil; in Russian - Богатство спеси сродни; Богатый никого не помнит - только себя помнит; Богатый совести не купит, а свою погубляет; Изведай человека на деньги; Деньги искус любят; in Romanian - Când ai bani, ai și dușmani (It means that having money can lead to envy); Prea multă bogăţie prosteşte oamenii. The second group includes the proverbs: in English - Where there's money, there's the devil; in Russian - Деньгами души не выкупишь; Грехов много, да и денег в волю; Деньги копил, да нелегкого и купил.

Money and thrift. In the proverbs of this group, it is stressed that it is important to save money to avoid poor old age. In the English language, we can find the following paremiological units: Money saved is money earned and Save your money and die rich. In the Russian language, there are the following proverbs underlining that wealth is the result of frugality: Деньги любят счет; Копейка рубль бережет; Богатство - вода: пришла и ушла; Ни конь без уздь, ни богатство без ума; Деньги пух - только дунь на них - и нет. In the Romanian language, we can encounter some proverbs about saving money: Celui cu economie suta î este o mie; Când ai bani, gândeşte-te la ziua când nu-i vei mai avea; Cine economiseşte banul, trăieşte fără griji; Cine nu respectă bănuţul, nu e demn de un ban mai mare.

Money is the result of work. This semantic group includes proverbs that demonstrate that to earn money a person should make efforts and that earning money is more important than spending. The following paremiological units belong to this group: in English - Money doesn't grow on trees and Earn money before you spend it; in Russian - Денежки труд любят; in Romanian - Banul muncit пи se prăpădeşte.

Unlike in the Russian and Romanian, in the English language, there are proverbs showing the relevance of money, its universal nature: Money never comes out of season; Money in the purse will always be in fashion and Money doesn't get dirty. English people often treat money with humor: People are funny about money and Nothing but money is sweeter than honey. 


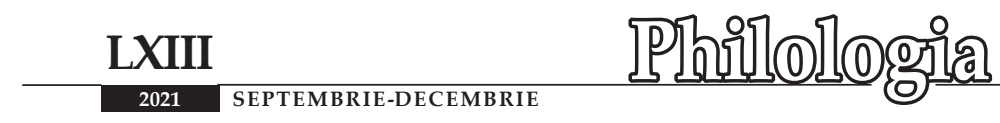

A distinctive feature of proverbs about money in Russian and Romanian is that some of them deal with a religious theme, expressed through lexemes such as «грех», «Бог» and «ад» in Russian, „raiul” and „Dumnezeu”. In the Russian language, we can encounter the following proverbs: Бог любит веру, а деньги счет; Деньга попа купит и Бога обманет аnd Пусти душу в ад-будешь богат. In the Romanian language there are such religious proverbs as Aurul deschide raiul; $C u$ chei de aur şi argint se deschid porţile raiului and Dacă vrei să ştii ce părere are Dumnezeu despre bani, uită-te numai la ce fel de oameni îi dăa. These examples testify to the exceptional role of religion in the life of Russian and Moldovan people.

Another characteristic of money-related proverbs in the Russian language is that some of them contain the lexemes «рожь», «обоз», «конь», for example, Есть грош, так будет и рожь; Копейка обоз гонит; Ни конь без уздь, ни богатство без ума. The use of such lexical units as „rye”, „wagon train” and „horse" in proverbs is explained by centuries-old economic structure in the past: Russian was an agrarian county where most of the population worked in the sphere of agriculture.

It should be noted that the semantics of Russian proverbs is inextricably linked with background cultural knowledge. So, the paremiological unit Денежки на стол, а изба на простор reflects the Russian tradition of taking ransom from the bride's parents. The proverb Наживной рубль - дорог, даровой рубль дешев indicates that in Russia the money received unexpectedly is often wasted (Denisenkova, 2015, p. 37).

In Russian linguaculture, wealth is burdensome, it is a source of illness and anguish: Богатому не спиться, богатый вора боится; Много денег - много и хлопот; Через золото слезы льются; Нищий болезней ищет, а к богатому они сами идут. Poverty has traditionally been perceived as a positive quality: Богатство гинет, а нищета живет; Меньше денег, меньше хлопот; Лишние деньги -лишняя забота. English people have a positive attitude towards richness and a negative one towards poverty.

As already mentioned, money is one of the basic values in modern society. At the same time an important role in the creation of the system of values is played by the concepts laid down in linguistic and cultural aspects and implemented through proverbs. As a result of the research on the linguistic material of English, Russian and Romanian languages, similar and unique meanings of proverbs were selected and systematized which in the process of rethinking acquired a deep generalization. The paremiological units in the corresponding linguacultures reflect the idea that money is power in our society, but they also highlight its corruptive nature.

Despite certain similarities, the paremiological units in English, Russian and Romanian reflect the national and cultural information in different ways. In our perception, there dominate proverbs, where money is not the main component of life, while in the mentality of the English people, a more detailed view of money as a universal criterion of the life quality is presented. A distinctive characteristic of proverbs about money in Russian and Romanian is that some of them deal with 
a religious theme. Unlike the Moldovans and the Russians, the English people generally regard money and wealth in a positive way.

In the course of analysis, it was revealed that the difference between English and Russian proverbs is largely due to the difference in their origin. A significant part of English proverbs are maxims, short sayings that were formed under the influence of Latin expressions and quotations of famous people. They reflect the mentality of city dwellers, merchants, business people, which is expressed in linguistic means. Russian proverbs reflect the mentality of peasants and are closely related to the concrete-figurative worldview. The emotional component in the Russian and Romanian money-related proverbs is higher due to the use of elements of folk culture.

\section{Bibliographical References:}

COLENCIUC, Inna. Functional-Semantic Field "Money" in the English Language. In: Intertext. 2016, nr. 3-4, p. 103-109.

Dal' = ДАЛЬ, Владимир. Пословищы русского народа: Сборник в 2-х томах. Москва: Художественная литература, 1984.

De la lume adunate. Proverbe româneşti. Chişinău: Hyperion, 1992.

Denisenkova $=$ ДЕНИСЕНКОВА, Юлия. ПословицЫ о деньгах в русской культуре. In: Вестник МГИМО. 2015, nr. 2, p. 35-37.

DRAGAN, Elena. Cultorologia lingvistică. Bălți: Univ. de Stat „Alecu Russo”, 2010.

HJELMSLEV, Louis. Outline of Gloseosemantics. Copenhagen: Nordisk sprod-og kulturvorlag, 1997.

MIEDER, Wolfgang. Proverbs: A Handbook. Westpork: Greenwood Press, 2004.

NORDAHL, Grieg. Wisdom: Proverb Features. New York: Routledge, 2011.

NORRICK, Neal. How Proverbs Mean. Berlin: Mouton, 1995.

Osheva = OШЕВА, Елена. Концепт «Деньги» в англо-американских пословицах и поговорках. In: Вестник МГИМО. 2013, nr. 5, p. 227-231.

Permjakov = ПЕРМЯКОВ, Григорий. Основы структурной паремиологии . Москва: Восточная литература, 1988.

The Dictionary of Modern Proverbs. New Haven Connecticut: Yale University Press, 2012.

WHITING, Barlette. Proverbs, Sentences and Proverbial Phrases. Cambridge: Massachusetts: Harvard University Press, 2007. 